\section{İstanbul Üniversitesi İletişim Fakültesi Dergisi Istanbul University Faculty of Communication Journal}

ISSN $1302-633 X$
İTANBUL

UNIVERSIT Y

P R E S S

\title{
Kadınların Madun Sorunsalı ve Bir Alternatif Olarak Yeni Medyada Dijital Aktivizm: Change.org
}

\section{Change.org: The Problem of Subaltern in Women and Digital Activism in New Media as an Alternative}

\author{
Selin KİRAZ ${ }^{1}$, Seyra KESTEL ${ }^{2}$
}

'Instructor, Istanbul Esenyurt University, Vocational School, Istanbul, Turkey ${ }^{2}$ Res. Assist., Istanbul Esenyurt University, Faculty of Arts and Social Sciences, Istanbul, Turkey

Sorumlu yazar/Corresponding author: Selin Kiraz,

İstanbul Esenyurt Üniversitesi, Meslek Yüksekokulu, Radyo ve Televizyon Programcılığı Bölümü, İstanbul, Türkiye E-posta/E-mail: kirazselin@gmail.com

Geliş tarihi/Received: 15.06.2017 Kabul tarihi/Accepted: 24.11.2017

Atıf/Citation: Kiraz, S., \& Kestel, S. (2017). Kadınların madun sorunsalı ve bir alternatif olarak yeni medyada dijital aktivizm: Change. org. İstanbul Üniversitesi Illetişim Fakültesi Dergisi, 53, 139-163.

https://doi.org/10.17064/iuifd.321654
Öz

Tarihsel süreç içerisinde 'madun' kavramı ilk kez hegemonya ile ilintili olarak Antonio Gramsci tarafından 'subaltern' terimiyle ortaya atılmıştır. Gramsci'nin bu tanımı günümüzde 'ezilen' ya da 'öteki' olarak tabir ettiğimiz, toplumda sesi duyulamayan kişileri kapsamaktadır. Bu konuda güncel tartışmaların önünü açan bir diğer isim; Gayatri Chakravorty Spivak'tır. Madun kavramı; Gramsci ve Spivak tarafından birbiri ile bağlantılı ancak belli noktalarda ayrışan tanımlamaları barındırmıştır. Spivak'a göre asıl sorun; madunun sesinin duyulamıyor olmasından ziyade hiç konuşamamasıdır. Bu bağlamda; madun kavramını değerlendirdiğimizde karşımıza en çok toplumsal cinsiyetin neden olduğu hegemonik eşitsizlikten doğan kadınların sorunları ortaya çıkar. Toplumsal cinsiyet ekseni ve ataerkil hegemonyada madun olarak konumlanan kadınların hegemonya karşısında başkaldırabilmesi için alternatif bir alanın oluşması, madunun konuşması bağlamında önem taşımaktadır. Yeni iletişim teknolojileri madunun hegemonyaya karşı durabileceği alanlarını genişletirken, aktivist hareketlerin de dijitalleşmesini sağlamıştır. Bu makale; www. change.org'ta yer alan kadınlarla ilgili kampanyaları madunun hegemonyaya karşı durabileceği alternatif bir kanal olması bağlamında ele alarak, dijital aktivizm ile ilintili olan etkinliğini araştırmaktadır. Araştırmanın ana amacı; yeni iletişim teknolojilerinin gelişmesiyle birlikte alternatif kanalların ortaya çıkmasının örgütlenme bağlamında ne ölçüde başarı sağladığını saptamaktır. Çalışmada change.org'ta 1 Ocak 2016 ile 1 Mayıs 2017 tarihleri arasında Türkiye'de başlatılmış olan kadınlara yönelik kampanyalar içerik analizi yöntemiyle incelenerek sonuçlar değerlendirilmiştir.

Anahtar Kelimeler: Madun, dijital aktivizm, change.org

\section{ABSTRACT}

From a historical perspective, the concept of "subaltern" was first introduced by Antonio Gramsci in 1930 in relation to hegemony. However, the present day definition of subaltern includes people who are termed "oppressed" or "the other," and their voices are unheard in society. Gayatri Chakravorty Spivak's term, "the other" is another name that makes this issue controversial. Gramsci and Spivak's 
views on this subject are not only associated with each person but also separated at certain points. According to Spivak, the main problem is that subalterns can-not speak; in other words, their voices cannot be heard. In this context when we use the concept of subaltern, the biggest issue we are facing is the problems faced by women, which in turn arise from the hegemonic inequality caused by gender. A woman can be identified as a subaltern because of social gender axis and counter-hegemony. New communication technologies have broadened the counter-hegemony areas of subalterns, while also ensuring the digital activism movements. For instance, with the widespread use of new communication technologies, almost everyone is able to use these technologies, and those who can-not physically have a power of opposition to the dominant ideology can create new formations through these channels. This article focuses on the campaigns related to women, which reflect the counter-hegemony efforts of subalterns and the effectiveness of such efforts in terms of digital activism that appears in www.change.org. In this study, women's campaigns, launched in Turkey between January 1, 2016 and May 1, 2017 on change.org, were examined through content analysis and their results were evaluated.

Keywords: Subaltern, digital activism, change.org

\section{EXTENDED ABSTRACT}

From a historical perspective, the concept of "subaltern" was first introduced by Antonio Gramsci in 1930 in relation to hegemony. However, the present day definition of subaltern Gramsci includes people who are termed "oppressed" or "the other," and their voices are unheard in society. Another theorist that gives rise to current discussions on this issue is Gayatri Chakravorty Spivak. Gramsci and Spivak's views on this subject are not only associated with each person but also separated at certain points. According to Spivak, the main problem is the subaltern's inability to speak, rather than being inaudible. Hereunder, it is impossible to speak for subaltern. In this context, when we use the concept of subaltern, the biggest problems that we are facing are women's problems arising out of a hegemonic inequality and caused by gender. A woman can be identified as a subaltern because of social gender axis and counter-hegemony. New communication technologies have broadened the counterhegemony areas of subalterns, while also ensuring the digital activism movements.

This article focuses on women's campaigns, which are related to counterhegemony efforts of subalterns, and their effectiveness in terms of digital activism that appears on www.change.org. In this study, a content analysis of women's campaigns, launched in Turkey between January 1, 2016 and May 1, 2017 on Change. org, are conducted, and the results thereof are evaluated.

In this context, answers to the following research questions are sought:

Between the related dates, how many campaigns were launched about women's issues, and what are their success rates? 
Between the related dates, what kinds of organizations were made and what are their success rates?

Who are the campaign initiators and who are the receivers? What are their success rates?

What is the key role of the new communication technologies to create counterhegemony?

In this study, a content analysis was conducted through the above-mentioned research questions. Content analysis is a type of descriptive research method. Therefore, www.change.org was chosen as the communication resource sample of the study. As sample documents, women's campaigns on the web site were specified, and they were limited to the period between January 1, 2016 and January 5, 2017,

From January 1, 2016 to May 1, 2017, a total of 226 women's campaigns were launched on www.change.org, and only 26 of these campaigns were successful. Most of these campaigns were about violence against women (44.6\%).

As per the statistics derived from the analysis, the most successful campaigns are about improving women's representation in the media vehicles.

The success rate of the campaigns, which were launched for increasing women's employment as well as improving their working conditions, is $6.7 \%$. In addition, $5.8 \%$ of the campaigns, which are regarding gender equality and positive discrimination in social as well as legal rights, were successful.

The campaigns on those dates were $57.5 \%$ launched by women, $26 \%$ by men, and $16.3 \%$ were launched by different organizations or platforms.

Between the limited dates, a total of 59 men launched campaigns about women's issues. Most of them launched campaigns on the web site after a case of violence against women occurred.

Receivers of the campaigns about women's issues are governmental authorities, bureaucrats, constitutional and security units, opposition parties, and local 
government members—such as governors and mayors. Since most campaign efforts are about violence against women, especially Ministry of Justice was targeted in the campaigns. The Ministry of Social Policies and Family and the Ministry of Interior were also targeted in the campaigns.

Between January 1, 2016 and May 1, 2017, 26 of the 226 campaigns that were initiated on women issues were successful, and they created a change. The measure of success of a petition is to create change, as well as reaching the target number of signatures; as some of the petitions could not create any change even though they reached the target number of signatures. We do not consider these petitions as successful within our study. When we pay attention to receivers, the most successful campaigns are the ones sent to media companies and the Radio and Television Supreme Council (35.8\%). The other ranking rates are: private companies $(21.7 \%)$, political parties (19\%), the Grand National Assembly of Turkey (15.6\%), Presidency of the Republic (10\%), Ministry (9.7\%), Security and Forensic Units (6.3\%) and Prime Ministry (3.2\%).

New media and technologies help the society in making developmental progress; further, the voices of the subaltern can be heard by creating alternative media channels. Subaltern who can-not hear the voice in the traditional media can include digital activism by the development of new media technologies and can be heard. The campaigns of Change.org save individuals from being subalterns in the "context of discourse," and the oppressed can make themselves audible through these new media. 


\section{GíRiş}

Madun, Subaltern olarak adlandırılan, Latince sub (alt) ve alter (öteki) sözcüklerinin birleşiminden türeyen, ilk olarak Antonio Gramsci tarafından İtalya'nın güneyindeki dağınık ve parçalı bir görüntü arz eden yoksul tarım işçilerini ve köylüleri tanımlamak için kullanılmıştır. Madun, en genel kapsamıyla ekonomik, sosyal, politik ve kültürel olarak, homojenize iktidar hegemonyasının yapısal olarak dışındaki gruplar şeklinde adlandırılabilmektedir (Somay, 2008, p. 155).

Gramsci'nin ilk kez hegemonya modelini oluştururken kullandığı madun kavramı "ezileni" tarif ederken kullanılmasının yanı sıra, ezilene iktidar ağlarıyla örüntülü ve erkinlikten uzak bir alan sunmaktadır. Madunun arzularından kaynaklanan bir bilincin varlığı, ezileni hegemonyaya karşı durabileceği bir alana doğru sürüklemektedir. Bu bağlamda Gramsci'nin karşı-hegemonya kavramını da açıklamak yerinde olacaktır. Karşı-hegemonya özünde yönetici olan sınıfın ihmal ettiği kültür alanında yürütülecek ideolojik ve siyasal yeniden anlamlandırmanın bir ürünüdür ve bu alanda madun direnişle bağlantılı olarak tanımlanmaktadır. Bu bağlamda, toplumsal cinsiyet rejimi içerisinde madun konumunda yer alan kadınların direnişi hegemonya karşısında durabilmede önem taşımaktadır (Gramsci, 1971, pp. 152-153).

1980'lerin ortasında madun kavramına kuramsal bir boyut kazandıran ve maduniyet çalışmalarının temellerini atan kuşkusuz ki Gayatri Chakravorty Spivak olmuştur. Tüm bu çalışmaların merkezinde olan soruyu Spivak sorar: Madun konuşabilir mi? Daha da önemlisi "kendi adına" ve "kendi sesiyle" konuşabilecek mi? Son olarak, madunun konuşabiliyor olması onu madun olmaktan çıkarır mı? (Spivak, 2009, p. 53).

Dünyayı ekonomik, politik ve sosyal anlamda etkileyen ve kişilerin yaşayış tarzlarını, birbirleriyle olan iletişimini, kendilerini ifade ediş biçimlerini dönüştüren yeni iletişim teknolojileri, özellikle telekomünikasyon ağlarının genişlemesi ve internetin de yaygınlaşmasıyla birlikte küresel sistemin vazgeçilmez bir unsuru haline gelmiştir. Yeni iletişim teknolojileriyle birlikte hem devletler ve şirketler bunu güvenlik, bilgi ağı oluşturma, bilgiyi arşivleme, ideolojik söylemi iletme, üretim ve tüketim faaliyetlerini yönetme gibi işlevleri artık çok daha hızlı, kolay ve geniş bir kitleye karşı gerçekleştirebilmekte, hem de gündelik hayatın içine kadar nüfuz eden bu teknolojik yapı sayesinde birey, kendini ifade edebilmek için birçok alternatif bir alan yaratabilmektedir. Yeni iletişim teknolojileriyle değişen iletişim biçimlerinin yanı 
sıra, özellikle son yıllarda oluşan dijital aktivizm ise ağlar aracılığıyla örgütlenen yeni bir toplumsal hareket alanı sağlamıştır.

Peki, madunun konuşamayacağını ve duyulamayacağını ilân etmekten ziyade onu dinleyebilmeyi öğrenebilecek bir konuma geçebilmenin araçları neler olabilir? Hegemonyaya karşı durmanın ve direnişin alanları, yeni iletişim teknolojileriyle beraber hem gelişmiş hem de bu kampanyalar aracılığılla örgütlenmeler büyük bir ivme kazanmıştır. Toplumun "öteki" kısmında kalan madun bireyler veya madun adına siyasi erklere sesini duyurmak isteyenler, yeni medya teknolojilerinin toplumsal hareketlere kazandırdığı gelişmeler sayesinde belli kampanyaların çatısı altında örgütlenme yaratabilmektedir. Tam da bu noktada, dijital aktivizm madunun sesini duyurarak değişim yaratma açısından önem taşımakta ve bu bağlamda da hem dünyada hem de Türkiye'de imza kampanyası başlatarak faaliyet yürüten "change. org" başarılı bir örnek teşkil etmektedir.

\section{Madun ve Hegemonya Kavramları Bağlamında Kadınlar}

Madun en genel tanımıyla; alt ve aşağı konumda olan dinamik farkın heterojenliğini ifade etmektedir. Gramsci, bir toplumda sesi olmayan, kendilerini temsil edemeyen, toplumun işleyiş mekanizmaları içerisinde kendini ifade edemeyen işçiler, köylü kadınlar gibilerinin klasik Marksist anlamdaki proleteryadan başka bir durumda olduğunu belirtmek amacıyla bu kişileri "madun" olarak tanımlamıştır (Yetişkin, 2013). Gramsci'nin bu tanımına göre, madun tam anlamıyla özne ile ilintili olarak kavramsallaştırımaktadır. Toplum nezdinde özne olarak atfedilen bireylerin temel özelliği konuşmaktır, ancak bu tanımlamaya göre madunlar birey olarak konuşamamakta, bu nedenle de özne kavramının tamamen dışında kalmaktadır.

Hegemonya, Gramsci'ye göre toplumun her kesiminde belirli bir üstünlük kurma olarak tanımlanmakta olup, madun kavramı da hegemonyaya maruz kalma ile ilintilidir. Gramsci'ye göre hegemonya; kapitalist bir ekonomik sistemde temel bir sınıfın diğer müttefik sınıfları yanına alarak, karşıt ve tabi sınıf ya da sınıflarlar arasındaki mücadele pratiği içinde ulaşılan ve nihai olarak da sistemin bir bütün olarak yeniden üretimini olanaklı kılan bir ideolojik sentezdir (Gramsci, 1971).

Gramsci'nin hegemonya tanımında ideolojik bir mücadelenin varlığı karşıhegemonyayı da mümkün kılmaktadır. Hegemonyanın toplumun her bir parçasının 
anlam ve değerlerine egemen bir güç oluşturamayacağı gerçeği karşı-hegemonyanın varlığını bir anlamda kabul etme olarak tanımlanabilmektedir. Gramsci'ye göre; karşıhegemonya mücadelesinde en önemli unsur; var olan hegemonyanın kurucu öğeleri üzerinden çalışmak ve onları yeniden şekillendirmek, zaten var olan bir söyleme ekleme yapmak, onu genişletmek ve dönüştürmektir (Kıvılcım, 2013). Bu nedenle, sivil direnişler ve örgütlenmeler, hegemonik olan güçlere karşı bir alternatif hegemonya alanı oluşturmada oldukça önem taşımaktadır. Özneden dışlanan madun, arzu ve bilinciyle birtakım dirençlere yönelebilmekte ve tam da bu noktada konuşup konuşamaması kavramı sorgulamaya itmektedir.

Gayatri Chakravorty Spivak (1988) "Madun Konuşabilir Mi?" adlı makalesinde madunu; "hegemonik güçlerin dışında kalanlar, temsil edilemeyenler, sesi kaybolmuşlar" olarak tanımlarken, makalesinin başığındaki soruya da yanıt aramaktadır. Epistemik şiddet tarafından sınırları çizilmiş döngüdeki kenarları ele alırken; "Batılı özne", "özne olarak Batı", "egemen sınıf" kavramlarını da ele alır. Bunun yanı sıra, Foucault ve Deleuze'in egemen sınıfın dışında yer alan işçi sınıfından yola çıkarak, sesi zor çıkanları anlamaya çalıştıkları sohbetlerinde madunla ilgili konulara değinen tanımlamalarla çalışmanın sınırlarını belirlemiştir. Spivak, makalesinde madun konusuna feminist yaklaşımla yaklaşmakta ve madun olarak sıklıkla kadınları ele almaktadır.

Maduniyet, alt ve aşağı konumda olmaktan dolayı duyulan sıkıntıdan ve şikâyetten çok, tekilliğin ve çeşitliliğin siyasi, ekonomik ve kültürel üretim hatlarına girememesi ile ilgilidir. Madun en geniş anlamıyla, ekonomik, siyasi ve kültürel üretim ilişkilerinin içine dâhil olsa dahi tekilliğini ifade edemeyen ve egemen olana tabi, alt ve aşağı konumdaki 'başka' olandır (as cited in Yetişkin, 2010).

Spivak'ın (1988) madun tanımlamasındaki en önemli sorun alanı kadınlar olarak yer almakta ve madunu şu ifadelerle sorgulamaktadır:

Madun öznenin silinmiş güzergâhı içinde, cinsel farkın izi iki misli silinir. Buradaki sorun kadınların ayaklanmaya katılımı sorunu ya da cinsiyete dayalı işbölümünün temel kuralları değildir, her ikisi için de 'kanıt' vardır. Sorun daha ziyade, toplumsal cinsiyetin ideolojik inşasının, hem sömürgeci tarih yazımının nesnesi olarak hem de ayaklanmanın öznesi olarak eril olanı egemen tutmasıdır. Eğer, sömürgeci üretim bağlamında, madunun tarihi yoksa ve konuşamazsa, kadınlar olarak madun daha derinden gölgededir. 
Söz konusu madun tanımlamaları birçok ötekileştirmeyi (dinsel, ırksal, cinsel) genel anlamda kavramın içeriğinde barındırmaktadır. Diğer birçok ötekileştirme gibi cinsiyet kökenli ötekileştirmeler de hegemonya sonucu oluşmaktadır. İdeolojik ve toplumsal ataerkillik bir hegemonya alanı oluştururken, kadınlar bu sıkışmada Spivak'ın tanımında yer alan alt ve aşağıya çekilmektedir.

Bazı feminist hareketler ve kadınların direnişleri, sivil örgütlenmeler ile ilintili olarak, kadınlara konuşma alanı yaratmakta, her zaman madun olmasa bile madun adına konuşabilecek bireyler ve örgütlenebilecek çeşitli alanlar ortaya çıkarmaktadır. Gelişen yeni iletişim teknolojilerine paralel olarak ortaya çıkan "dijital aktivizm" tanımı, maduna günümüzde hegemonya karşısında örgütlenebilmede önemli bir işlev sunmaktadır.

\section{Yeni İletişim Teknolojileriyle Oluşan Dijital Aktivizm}

Tüm dünyada teknolojiye yapılan yatırımlar, onun hızla gelişmesini sağlamış, günümüz toplumları artık iletişimlerini büyük bir oranda bilgi teknolojileri yoluyla sağlamaya başlamışlardır. Özellikle 1970'lerde internetin kullanılmaya başlanması, yeni yazılımlar, 80'ler ile birlikte bu teknolojilerin kapsama alanlarının genişlemesi ve 90 'lar ve 2000 'lerde artık internete ulaşamayan neredeyse hiç kimsenin kalmayışı önceden fiziksel güç ya da mücadele gerektiren birçok olayın sanal ortamlara hızlı adapte olmasını beraberinde getirmiştir. Artık kitleler, yurttaş gazeteciliği veya blog yazarlığı gibi faaliyetlerle bilginin hem üreticisi hem de tüketicisi haline gelmişlerdir. Halkın, temsilin doğasının yapılandırımış olduğu konusunda giderek daha çok farkına vardığı internet, medya dönüşüm çağı için mükemmel bir araçtır (Andrejevic, 2014, p. 64).

Illetişim teknolojileri ile birlikte internetin yaygınlaşması dijital aktivizmi de yaşam pratiklerine dâhil etmiştir. Dijital Aktivizm, kişilerin, gelişen iletişim teknolojilerini kullanarak birçok konu ya da olayla ilgili görüş, düşünce, tepki ya da desteklerini ifade etmek ve onları pratiğe dökmek adına yaptıkları faaliyetleri kapsamaktadır. Ayrıca, günümüzde birçok toplumsal faaliyet ya da sosyal sorumluluk kampanyaları, internet destekli sanal mecra ve teknolojik platformlara taşınmıştır. Online haber siteleri, geliştirilen alternatif medya mecraları ve son olarak hayatımıza bütünüyle dâhil olan sosyal medya, geleneksel iletişimin yanı sıra artık internet destekli iletişimden de yararlanıldığı, yeni iletişim teknolojilerinin daha bağımsız olabilme yolunda bir 
alternatif sunduğu görülmüştür. Günlük hayata eklemlenen bu teknolojiler medyadan bankacılık faaliyetlerine, sosyalleşme ortamlarından alışveriş ve eğlenceye kadar birçok pratiği de dönüştürmüş, bireylere söz konusu pratikleri fiziksel bir çaba sarf etmeden gerçekleştirme olanağı sunmuştur. Bu nedenle dijital aktivizm son derece etkili, fazla bir maliyet gerektirmeyen, çoksesliliği temel alan mutlakçılığa yönelik bir faaliyettir (Uçkan, 2012).

Iletişim teknolojileri ile paralel gelişen, radyo, televizyon ve gazete gibi geleneksel kitle iletişim araçlarından olan farklılı̆ı ile yeni medyayı temsil eden internet, aktivistler tarafından birbirleri ile iletişim kurmak ve belirli konularda yapmayı planladıkları eylem ya da gösterileri örgütlemek için sıklıkla kullanılmaktadır. Birçok farklı aktivist grup yeni iletişim teknolojilerini kullanarak seslerini duyurmaktadır (Considine, 2009).

Internet, daha önce de bahsedildiği üzere etkileşimli olması ve hedef kitleyi içerik üreticisi konumuna getirmesi gibi özellikleri nedeniyle günümüzde çok önemli bir yere sahiptir. (Doğu, 2014, p. 29). Kamusal alanı da dönüştürdüğü ve birçok sosyal platformu sanal birer kamusal alan haline getirdiği varsayılan internet, (Castells, 2007, p. 1-2) savaş ve çatışma gibi çözüm arayışlarının yerine, online ortamlarda tartışma ve uzlaşmayı getirerek, daha demokratik bir platform olabilme yolunda kayda değer bir misyon üstlenmiştir. Bu noktada internetin toplumsal bir eylem olan aktivizm kavramını da kendisine dahil ederek, dönüştürdüğü ve onu online bir biçime sokarak internet aktivizmi ya da dijital aktivizm kavramını gündelik yaşama dahil ettiğini söylemek de yerinde olacaktır. Dijital aktivizm, bireylerin internet teknolojilerini kullanarak duygu, düşünce ve tepkilerini ifade ettikleri bir biçim olarak aktif bir şekilde yürütülmektedir. Dijital aktivizm, insan hakları ile inceleyeceğimiz üzere kadınların hakları, çevre ve hayvan hakları gibi çeşitli sosyal, siyasal ve toplumsal konular hakkındaki tepki, destek ve öfke gibi duygu ve düşüncelerini online bir şekilde eylemleştirmek anlamında dijital platformların kullanılması şeklinde açıklanabilir.

Medya, dijital aktivizmden hızı ıçerik ve dünyayı heyecanlandırmak için siyasi ya da toplumsal hareketler noktasında bir etkili bir şekilde faydalanmış ve birçok aktivistin online aktivizme yönelmesi medyanın yönlendirmesi ile gerçekleşmiştir (Kahn \& Kellner, 2004, p. 87). Buna karşın dijital aktivizm ile sivil ya da toplumsal hareketler arasında önemli bağlar kurulsa da yani söz konusu hareketlerin dijital 
aktivizm ile geçmişe oranla çok daha kolay ve etkili şekilde kitlelere ulaştığı varsayılsa da, bazı araştırmalar bu pratiğin zaman zaman etkisiz kaldığını, belli konularda yaygınlık kazanamadığını da göstermektedir (Lewis, 2014, p. 1).

Dijital aktivizm doğrudan internet ile sınırlı faaliyetler (internet üzerinden başlatılmış bir faaliyete destek verme) ve herhangi bir faaliyet için internet üzerinden örgütlenme biçiminde ikiye ayrılabilmektedir. Örneğin bireyler gerçekleştirecekleri bir protesto yürüyüşünü Facebook ve Twitter gibi sosyal paylaşım siteleri üzerinden örgütleyebilmektedir. Söz konusu sosyal paylaşım sitelerinden yapılan çağrı gibi bireylere elektronik posta yolu ile ulaşma da dijital aktivizmi başlatır. Bireylerin Facebook ya da Twitter'daki şahsi hesaplarında dijital aktivist bir pratiğe ilişkin bilgi, görsel, çağrı ya da davet paylaşımı da söz konusu pratiğe internet destekli hız kazandııır ve kolaylıkla kitlelere ulaşım sağlar.

Dijital aktivizmin boyutu ile internet tabanlı aktivizmin gücü, siyasetçiler, güvenlik güçleri ve küresel şirketleri daha dikkatli davranmaya itebilmektedir. Örneğin, Amerika Birleşik Devletleri'nde polis tarafından şüpheli görülüp öldürülen siyahi bir genç olan Trayvon Martin için sosyal medyada yürütülen ve ünlülerce de desteklenen kampanya, güvenlik güçleri üzerinde büyük bir baskı yaratmayı başarmıştır.

Bu örnekler Lincoln Dahlberg'in Dijital Demokrasiyi Yeniden Yapılandırmak: Dört Pozisyona Dair Bir Taslak adlı makalesinde yer alan, dijital demokrasiyi anlamaya yönelik dört pozisyondan biri olan Liberal-Bireyci Dijital Demokrasi sınıfına girmektedir. Bu pozisyon, liberal politik sistem içinde özel çıkarlarını gerçekleştirmelerini sağlamasından dolayı bu şekilde adlandırılır. Bu yaklaşıma göre dijital medya, bireylerin yarışan siyasal pozisyon ve problemlere ihtiyaç duydukları haberleri elde etmesine ve tercihlerini dijital ortamda başvuru ve kitle oluşturma olarak ortaya koymada araç olarak anlaşılır. Buna bir dizi e-demokrasi adını da verebiliriz (Dahlberg, 2017, p. 135).

Yeni iletişim teknolojilerinin toplumsal alana yayılımındaki en büyük gelişmelerden biri olan dijital aktivizmin iki alt türünden de bahsetmek gerekir: Slaktivizm ve Kliktivizm. Bu iki kavram çalışmanın devamında ele alınacak olan Change.org adlı web sitesinin kullanıcılarını da belirlememize ve sınıflandırmamıza yardımcı olacaktır. Slacktivizm, ilk kez 1995'de Dwight Ozard ve Fred Clark 
tarafından Cornerstone Festival'inde kullanılan terimdir ve en yalın açıklaması ile "durduğu yerden dijital eylem destekleme" anlamına gelmektedir (Christensen, 2011). Slacker (tembel) ve activism (aktivizm) kelimelerinden türetilmiş Slacktivism - Slaktivizm kavramı, eylem ve protestolara fiziksel olarak katılmayan, ancak durduğu yerden yazarak, yorum yaparak, like ederek retweet ederek, çoğunlukla sosyal paylaşım kanallarından destek ya da köstek olan kişilere verilen addır ("Slactivism", 2017).

Insanların kendilerini iyi hissetmek, kişisel olarak bir şey yapmış olduklarını düşünerek kendi tatminlerini sağlamak amacıyla yaptıkları pasif eylemcilik hareketleri slaktivizm olarak açıklanır. Katılınan kampanyanın bilinirliği ve çok insana ulaşarak yayılması gibi bir avantaj dışında slaktivist denilen pasif eylemci için "ben zaten bu iş için bir şey yaptım" duygusu yaşanacağından, aslında yapılması gerekenlerin yapılmaması, umursanmaması gibi sonuçlar da doğabilir. Tüm bunların yanında internetten imza kampanyalarına katılmak, belirli bir şeyi simgeleyen kurdele ya da bileklik takmak, teröre karşı milliyetçi simgeler, renkler gibi şeyler kullanmak, politik anlamlar içerdiği belirtilen takılar, rozetler kullanmak, stickerlar yapıştırmak, videolar dağıtmak, Facebook ya da Twitter gibi sosyal ağlarda profil fotoğraflarını ya da kişisel bilgilerini, ilgi alanlarını değiştirerek, çeşitli gruplara ya da sanal etkinliklere katılarak destek vermek çeşitli slaktivizm örnekleridir.

Bir takım toplumsal eylemleri, dönüşüm, iyileşme hareketlerini klavye başından örgütlüyen ve/veya destekleyen Kliktivistler ise birçok yönden Slaktivistlerden ayrılır. Bu kişiler, bunlar somut rakamlarla ve adımlarla, çok net hedeflerle internet temelli aksiyonlar, kampanyalar yürütmektedirler. Herhangi bir konuda toplumsal kaygı veya koruma gerekçesi ile bir şirketin ürünlerine karşı protesto kampanyası başlatmak, belirli eylemlere karşı site veya sosyal medya sayfaları açmak, imza kampanyaları oluşturmak Kliktivistlerin özellikleri arasındadır (Yegen, 2014, p. 90).

Peki tek bir 'klik' bir insanı ya da bir kitleyi, bir toplumsal hareketi örgütleyebilir, başarıyı getirebilir mi? Toplumsal dönüşüme, demokratikleşmeye, sorunların çözümüne yardımcı olabilir mi? Birçoğu online olarak yürütülen ve herhangi bir fiziksel mücadele içermeyen birçok kampanya nasıl, hangi koşullarda gerçekleşmekte ve devam etmektedir? Bu klikler, çalışmanın en büyük sorunsalı olan kadınları madun olmaktan kurtarabilir mi? Change.org örneği ile birlikte tüm bu sorulara cevap aranmıştır. 


\section{AMAÇ VE YÖNTEM}

Change.org'da yer alan madun (kadınlar) kampanyalarının hegemonyaya karşı durmada niceliksel olarak etkililiğinin belirlenmesi, dijital aktivizm hareketlerinde ne ölçüde başarılı olduğu ve madun konumunda yer alan kadınların hangi örgütlenmeler bağlamında sorunsallaştıııldığının saptanması bu çalışmanın ana amacını oluşturmaktadır. Bu bağlamda aşağıdaki araştırma sorularına yanıt aranmaktadır:

1. Belirlenen tarih aralığında kadınların sorunlarına ilişkin kampanyaların sayısı ve başarı oranı nedir?

2. Belirlenen tarih aralığında en fazla örgütlenmenin ana konusu nedir ve bu konulara göre başarı yüzdeleri nasıldır?

3. Kampanyayı başlatanlar (kaynak) ile kampanyanın muhatapları (alııı) kimlerdir ve başarı yüzdeleri nasıl gerçekleşmiştir?

4. Yeni iletişim teknolojilerinin hegemonya karşısında direnmedeki rolü nedir?

Çalışmada araştırma sorularının cevaplanması için betimsel araştırma yöntemleri arasında yer alan içerik analizi yönteminden faydalanılmıştır. İçerik analizi; sosyal bilimcilere arşivlerden, dökümanlardan ve kitle iletişim araçlarından elde edilmiş ham bilgilerin incelenmesi ve bir anlam kazandırılmasında sistematik bir metadoloji sağlayan bir yöntemdir (Demirci \& Köseli, 2011). Bu yöntem dâhilinde ilk olarak çalışmanın örnekleminde; iletişim kaynağı olarak www.change.org internet sitesi seçilmiştir. Örneklem dökümanları; internet sitesinde yer alan kadınlara yönelik oluşturulan kampanyalar olarak belirlenmiş, 01/01/2016 ile 01/05/2017 tarihleri arasında söz konusu sitede yer alan kadınlarla ilgili olan kampanyalar çalışmanın örneklemini oluşturmuştur. Bu tarih aralığının belirlenmesindeki en önemli sebep, son dönemde kadınlara yönelik başlatılan kampanyalarda kayda değer bir artışın gözlemlenmesi ve yapılan ön değerlendirme sonucunda bu kampanyaların geçmişe oranla değişime katkı sağlayacağının varsayılmasıdır. Ayrıca seçilen dönem, kadınların sorunlarına yönelik başlatılan kampanya sayısının en fazla ve en çeşitli olduğu zaman aralığını kapsamaktadır. Bu bağlamda, incelenen kampanya sayısı arttıkça, daha kapsamlı bir sonuç elde edileceğinden bir yıldan fazla bir süre tercih edilmiştir.

Araştırmanın örneklem hacmi genelleme yapmaya yeterli olacak miktarda olup, araştırma süresince objektif bir bakış açısıyla kategoriler ve kodlama cetveli oluşturulmuştur. Araştırma kategorileri oluşturulurken sınırlanan süre içerisindeki 
kadın sorunlarına yönelik olarak başlatılan toplam 226 kampanya tek tek incelenmiş, bu kampanyada ele alınan kategoriler ışığında yukarıdaki araştırma sorularına yanıt bulunmuştur. Ayrıca incelenen kampanyalar change.org internet sitesinin arşivlerinde yer aldığından araştırmanın tekrarlanabilir olmasını mümkün kılmaktadır.

\section{Madunun (Kadınların) Karşı-Hegemonyası ve Dijital Aktivizm Bağlamında "Change.Org" Kampanyalarının Analizi}

Change.org günümüzde en yaygın dijital aktivizm, slaktivizm ve kliktivizm örneklerinden bir tanesidir. Oluşum, belirli konularda imza kampanyaları düzenlemek noktasında dünyanın belki de en büyük sivil toplum dayanışma mecrası olarak tanımlanabilmektedir. Bağlantıya girdikten sonra yapılması gereken tek şey, 3 basit soruyu yanıtlamaktır: Kampanyanın kime yönelik olduğu, muhataplarından ne talep edildiği ve son olarak bunun kampanyayı başlatan kişi için neden önemli olduğunun anlatıldığı cevaplardan sonra kampanya aktif hale gelmektedir.

Insanlara nerede oldukları fark etmeksizin arzu ettikleri değişimi gerçekleştirme fırsatı sunan ve bir kliktivizm ve slaktivizm mecrası olan change.org, 2007 yılında aynı zamanda kuruluşun CEO'su olan Benjamin Michael Rattray tarafından kurulmuştur. Change.org'da, dileyen herkes bir konu ile ilgili imza kampanyası başlatabilmekte ve bir konuyu küresel çapta dikkat çekebilmektedir. Change.org özellikle sivil toplum kuruluşları ya da toplumların dezavantajlı kesimleri ile onların temsilcileri tarafından kullanılmakta ve Change.org'un tüm kampanyaları genellikle büyük ses getirmektedir.

Change.org'da çevre düzenlemesi, hayvan hakları, çalışma ve temel yaşam haklarını düzenleyen sözleşmeler ve siyasi düzenleme talepleri gibi talepler çerçevesinde imza kampanyaları yer almaktadır. Örneğin; "büyük evcil köpekler metro-tramvaylarda da seyahat edebilmeli", "antidemokratik seçim barajının kaldırılmasını talep ediyorum" ya da "hayvanlara işkence kabahat değil, suç sayılsın" başlıklı imza kampanyaları www.change.org'da öne çıkan kampanyalar olarak göze çarpmaktadır. Bunun yanı sıra kadınların hakları ile ilgili kampanyalar da özellikle son yıllarda en dikkat çeken kampanyalardandır.

196 ülkede 70 milyondan fazla change.org kullanıcısı bulunmakta ve toplumlar change.org aracılığı ile sorun olduğunu düşündükleri, bir şeyler yapılması gerektiği 
noktasında duyarlılık bekledikleri ya da destek almak istedikleri konuları kitlelerle paylaşmakta ve böylelikle bireysel mücadeleleri toplumsallaştırmaktadır.

Çeşitli ülkelerden kampanya direktörleri bulunan change.org'da başlatılan binlerce kampanya, yeni iletişim teknolojileri ve internetin etkin gücü ile başarıya ulaşmıştır. Change.org kendisini ücretsiz küresel kampanya platformu olarak tanımlamakta ve kendisini YouTube'daki sponsorlu videolar, Google'daki sponsorlu linkler ile Twitter'daki sponsorlu tweetler gibi pratiklerle kurumlardan sponsorlu imza kampanyası biçiminde aldığı reklamlar ile finanse etmektedir. Ayrıca pek çok farklı bakış açısını temsil eden sponsorlu kampanyalara ev sahipliği yapan ve herhangi bir kurum ile ilişkisi bulunmadığını söyleyen change.org, kişiselleştirme yaparak kullanıcılara kendi ilgi alanlarına yönelik sponsorlu kampanyalar sunmak adına da çalışmaktadır.

Change.org sitesi 2012 yılının eylül ayında Türkçeleşmiş ve change.org'un Türkiye ofisi de Eylül 2012 tarihinden itibaren resmi olarak açılmıştır. Change.org'un Doğu Avrupa ve Batı Asya Direktörü Dr. Uygar Özesmi, kurulduğu dönemde Türkiye'de aktif olarak 400.000 change.org kullanıcısı olduğunu ve her gün yaklaşık 10 adet imza kampanyası başlatıldığını ifade etmiştir.

Change.org'un "www.change.org" isimli resmi sitesinde ise, ana sayfada kullanıcıları ilk olarak "Dünyanın Değişim Platformu" sloganı ve "Bir Kampanya Başlat" çağrısı karşılamaktadır. Bunun yanı sıra sitede "Göz at" ve "Ara" bölümleri bulunmaktadır. Siteye ad, soyad, e mail ve kullanıcı tarafından oluşturulan bir şifre ile ya da opsiyonel olarak Facebook hesabı ya da kurum olarak üye olunabilmekte ve imza kampanyası başlatılabildiği gibi, destekçi de olunabilmektedir.

Sitede düzenlenmiş ve başarıya ulaşmış olan imza kampanyaları doğrulanmış başarı oranı, başlatan kişi ya da kurum ile destekçi sayısı, Facebook ile Twitter'daki beğeni sayısı ve kaç kişi imza verdi gibi ayrıntılar ile sunulmaktadır. Düzenlenen imza kampanyalarına ilişkin görseller ve kampanyanın başlatanı ile muhatabı da sitede açıkça verilerek, sitede imza kampanyaları konusunda yorum yapmaya olanak tanıyan bir kısım da bulunmaktadır. Bir dijital aktivizm platformu olan www.change.org'da düzenlenen birçok kampanya ana sayfada yer almakta, kampanyalarda "bu kampanyayı imzala", "Şu kadar imza verildi" ve "daha bu kadar gerekiyor" yönünde çağrılar da yer almaktadır. Kullanıcılar bir kampanya için imza verirken isim, soy isim, 
şehir, e mail ve imza vermek sizin için neden önemli gibi sorular ile karşılaşmakta, imzanı göster seçeneğini ise imza verirken opsiyonel olarak kullanabilmektedir. Ayrıca sitede kampanyalar için imza çağrısının altında kampanyayı oluşturan kimse tarafından tüm imza vermek isteyenler adına oluşturulan ve muhataptı hedef alan bir dilekçe de bulunmaktadır. Bununla birlikte kullanıcılar kampanyaları Facebook ve Twitter'dan paylaşarak yaymaya da davet edilmektedir. Sitede "En çok imza alanlar" başlığı altında en çok imza alan kampanyalar gösterilirken, kampanyaları Twitter'dan takip etmek adına link de verilmektedir. Ek olarak sitede; "Change.org hakkında", "Blog", "Kariyer", "Rehberler", "Yardım", "Basın", "Kurumlar", "Reklam", "Geliştiriciler", "Gizlilik Sözleşmesi", "Hukuki” ve "Reklam kuralları" kısımları da yer almaktadır. Ayrıca sitede hakkımızda kısmında yer alan "Bizimle çalışmak ister misin?" bölümünde Change.org'un kurumsal olarak çeşitli ülkelerde istihdam etmek için mühendislik, operasyon, tasarım vs. alanlarda yaptığı açık iş ilanları da bulunmaktadır. www. change.org'da ayrıca Türkçe, İngilizce ve Almanca da dâhil olmak üzere 18 adet opsiyonel dil seçeneği de mevcuttur (www.change.org). Change.org kliktivistlerin ve slaktivistlerin de kullandığı yaygın bir dijital aktivizm platformudur ve bireyler hem Change.org'da imza kampanyaları başlatarak, hem de başlatılan imza kampanyalarına "bir tık ile" destek olabilmektedir.

Çalışmanın kuramsal kısmında ele alınan madunun (kadınların) yeni iletişim teknolojileriyle birlikte ortaya çıkan dijital aktivizm yoluyla hegemonyaya başkaldırılabilecek yaratması için alternatif bir kanal olan "Change.org"ta , 01/01/2016 ile 01/05/2017 tarihleri arasında başlatılan imza kampanyalarına ait verilerin analizi aşağıdaki gibidir.

Kategorileme işlemi için belirlenen kategoriler; kampanyanın konusu (mesaj), kampanyayı oluşturan (kaynak), kampanyanın muhatapları (alıcı) ve kampanyaya niceliksel olarak katılım oranlarıdır. Bu bağlamda, kategorilerin tablolaştırılmasıyla; kadınların sorunlarında niceliksel olarak hangi konularda örgütlenildiği, konularına göre hangi kampanyaların değişim/başarı yarattığı, hangi konulara katılım oranlarının fazla veya az olduğu belirlenmiştir.

1 Ocak 2016 ve 1 Mayıs 2017 tarihleri arasında, www.change.org adresinde, kadınlara yönelik toplam 226 imza kampanyası başlatılmıs, bu kampanyalardan 26 tanesi amacına ulaşarak değişim yaratmıştır (Tablo 1). Bu nedenle belirlenen tarihler arasında başlatılan kadınların sorunlarına ilişkin imza kampanyalarının başarı oranı 
\%11,5 olarak saptanmıştır. Başarılı olan kampanyalar, amacına ulaşarak söz konusu alanda değişim yaratan kampanyaları ifade etmektedir. Örneğin, medyada kadınların temsiliyle ilgili olarak Aralık 2016'da Fatih Aydın tarafından başlatılan "Hasbro'nun Seksist Reklamı Yayından Kaldııısın" başlıklı kampanya kısa bir süre içerisinde 2860 kişinin destek vermesiyle yayından kaldırıımış ve kurumun sosyal medya hesabından silinmiştir. Değişim yaratan bu kampanyanın alıcıları ise; söz konusu marka ve RTÜK'tür (Aydın, 2016).

Başlatılan kampanya yüzdeleri incelendiğinde en fazla kampanya örgütlenmesi kadınlara yönelik şiddet üzerine başlatılan kampanyalar olarak saptanmıştır (yüzde 44,6). Şiddet temalı kampanyaların içeriğini; cinayet, cinsel istismar, hakaret, tehdit ve fiziksel şiddet oluşturmaktadır. Kadınlara yönelik şiddet temasından sonra, kadınların sosyal ve hukuki haklarını iyileştirme, değiştirme amaçlı başlatılan imza kampanyaları ikinci sırada yer almaktadır $(\% 33,5)$. Sosyal ve hukuki hakların içeriğini ayrıca kadınların istihdam alanlarını genişletme veya istihdam mekanizmalarını iyileştirme amaçlı başlatılan kampanyalar ile kadınların sağlık alanında erkeklerle eşit haklara sahip olabilme veya pozitif ayrımcılığı amaçlayarak yapılan kampanyalar oluşturmaktadır. Bu sıralamayı; yüzde 21,6 ile medyada kadınlar temsilinin toplumsal cinsiyet rejimi içerisinde kadınların 'öteki' olarak konumlandııımasını protesto amaçı başlatılan imza kampanyaları izlemektedir (Şekil 1).

Temalarına göre başlatılan kadınların sorunlarına yönelik kampanyalarının başarı istatistiklerine bakıldığında ise; en fazla başarıya ulaşan kampanyaların medyada kadınların temsilini iyileştirme amaçlı başlatılan imza kampanyaları olduğu görülmektedir. Belirlenen tarih aralığında başlatılan ve özellikle medyanın kadınları sunuş biçimini protesto eden kampanyalar \%28,5 oranıyla başarıya ulaşmıştır. Başarıya ulaşan bu kampanyalar sonucunda; çoğunlukla ilgili program yayından kalkmış, medyada yer alan şahıslar özür dilemiş veya hedef alınan reklamlar söz konusu marka tarafından yayından kaldırıımıştır. Şiddet kapsamında başarıya ulaşan kampanyaların yüzdesi ise 10,8'dir. Başarıyla sonuçlanan şiddet temalı kampanyaların içeriğine bakıldığında ise; oluşturulan kamuoyu neticesinde bazı hukuki yaptıımların gerçekleştiği görülmektedir. Son olarak, kadınların sosyal ve hukuki haklarına yönelik başlatılan imza kampanyalarında başarı oranı \%12,5 olarak saptanmıştı (Tablo 2).

Belirlenen tarih aralığında başlatılan kadınların sorunlarına ilişkin kampanyaların \%57,5'inin kadınlar, \%26'sının erkekler, \%16,3'ünün ise çeşitli platformlar tarafından 
başlatıldığı saptanmıştır (Tablo 3). Niceliksel olarak saptanan bu verilere göre; çalışma kapsamında madun olarak konumlandırdığımız kadınların karşı-hegemonya yaratmada, söz konusu internet sitesini etkin olarak kullandığı açıktır. Ayrıca madun adına çeşitli örgütlenmeler ve erkekler internet sitesi üzerinden kampanyalar başlatarak, madunun sesini ilgili muhataplara ve kamuoyuna duyurmayı amaçlamıştır. Yine internet üzerinden bazı platformlarlar, change.org'da kadınların sorunlarına yönelik kampanyalar başlatmıştır.

Kadınların başlattığı kampanyalar temalarına göre incelendiğinde; başlatılan kampanya sayısı en az medyada kadınların temsil sorunu alanında olarak saptanırken niceliksel olarak kampanya örgütlenmesi sayısının en fazla olduğu kampanya; şiddetten kaynaklanarak başlatılmış olan kampanyalardır. Tıpkı kadınlarda olduğu gibi; erkeklerin ve çeşitli örgütlenmelerin de başlattığı kampanyalarda niceliksel fazlalık; şiddet temasındadır. Özellikle kadınlara uygulanan herhangi bir şiddet (cinsel, fiziksel veya sözlü) sonrası başlatılan kampanyalar ve kadınlara şiddeti caydırıcı kılmaya yönelik anayasa düzenleme tekliflerini içeren kampanyalar şiddet konusundaki örgütlenmelerin içeriğini oluşturmaktadır (Tablo 4).

Toplam 130 kadının başlattığı kampanyalara bakıldığında; kadınlara yönelik şiddet temasından sonra en fazla sosyal ve hukuki haklar konusunda örgütlendiği saptanmıştır. Bu bağlamda kadınlar; sosyal ve hukuki hakları iyileştirme, istihdam ve sağlık gibi konularda çeşitli kampanyalar başlatmışlardır. Kadınların başlattığı kampanya temalarında son sırada ise medyada kadınların temsili yer almaktadır. Medyada kadınların temsilini toplumsal cinsiyet rejimi ekseninde sıkıştıran bazı markalara tepki gösterecek imza kampanyaları başlatılmış veya özellikle televizyonda yayınlanan bazı dizi ve programların yayından kaldırımasına dair destek toplamayı amaçlamıştır (Tablo 4).

Kısıtlanan tarih aralığında toplam 59 erkek, kadınların haklarına dair kampanya başlatmıştır. Erkeklerin başlattığı kadınlara yönelik kampanyalara bakıldığında ise yine en fazla örgütlenmenin gerçekleşen bir kadınların maruz kaldığı şiddet vakaları sonrasında olduğu saptanmıştır $(\% 59,3)$. Ayrıca sosyal ve hukuki hakları iyileştirme veya kendileriyle eşitlemeyi amaçlayan haklar kapsamında kampanya başlatan erkeklerin oranı \%30,3 iken, medyada kadınların temsilini eleştirerek, toplumsal cinsiyeti reklamlarına yansıtan markaları hedefleyen kampanya başlatan erkeklerin oranı ise \%10,1'dir (Tablo 5). 
Kadınlar ve erkekler haricinde kadınların sorunlarına ilişkin kampanyalar çeşitli dijital aktivist hareket başlatanlardan bir diğeri de; çeşitli örgütlenmeler ve platformlardır. Belirlenen tarih alanında bu platformların başlattığı kampanya sayısı 37'dir. Platformlar; bazı feminist hareketler, cinsiyetçiliğe karşı platformlar, çalışma birimleri ve derneklerdir. Kadınlar ve erkeklerde olduğu gibi, örgütlenmelerin de en fazla ses çıkardığı ve karşı hareket başlattığı kadınların haklarının ihlali alanında; kadınlara yönelik şiddet teması yer almaktadır $(\% 37,8)$. Tablo 6'da da belirtildiği gibi, bu örgütlerden \%35'i medyadaki kadınların temsili ve söylemine ses çıkararak kampanya başlatırken, \%27'si sosyal ve hukuki hakları kapsayan yasaların iyileştirmelerine dair çeşitli imza kampanyaları başlatmıştır (Tablo 6).

Dijital aktivizm ve hegemonyaya karşı durulabilecek bir alan yaratma bağlamında ele alınan kadınların sorunlarına yönelik kampanyalarının hangi muhataplara gönderilerek başarı amaçlandığı araştırma kapsamında önemli bir diğer sorunsaldır. Iletişim paradigmasının "kim, kime, neyi, nasıl söyledi ve etkisi nasıl oldu" olarak tanımlandığı (as cited in Öğülmüş, 1968) olduğu düşünüldüğünde kampanyanın alıcıları başarıı bir iletişim kampanyası yaratmada önemli bir rol oynamaktadır. Bu nedenle içerik analizi kapsamında kampanyaların niceliksel olarak en fazla ve en az hangi erklere, birimlere gönderildiği saptanmış, Tablo 7'de sayı ve oranları belirtilmiştir.

Tablo 7'de de belirtildiği üzere, başlatılan kampanyalar; çoğunlukla iktidara ait siyasi erklere, bürokratlara, anayasal ve güvenlikten sorumlu birimlere, muhalefet partileri ve iktidar partisine, vali ve belediye gibi yerel yönetimden sorumlu organlara iletilmiştir. Alıcıların en büyük çoğunluğunu bakanlar ve bakanlıklar oluştururken $(\% 29,3)$, şiddet temalı başlatılan kampanyalara paralel olarak özellikle Adalet Bakanlığı hedef alınmıştır. Bir diğer hedeflenen bakanlıklar ise; Aile ve Sosyal Politikalar Bakanlığı ve İçişleri Bakanlığı'dır.

Medyadaki toplumsal cinsiyetçiliği eleştirerek başlatılan kampanyalara paralel olarak alıcıların \%10,8'ini RTÜK ve medya kuruluşları oluşturmaktadır. Bu sıralamayı kâr amacı gütmeyen dernek ve sivil toplum kuruluşları izlemektedir. İçeriğine göre dernek ve STK'lara bakıldığında; kadın derneklerinin, feminist örgütlenmelerin ve insan haklarını korumayı amaçlayan bazı oluşumların ağırıklı olduğu saptanmıştır. Güvenlik ve adli birimlerin içeriğinde ise; yargıtay, savcllıklar, emniyet genel müdürlükleri yer almaktadır. Başlatılan aktivist hareketlerde mesajı alıcı olarak en 
fazla bakanlıklar saptanmışken, niceliksel olarak en az okullar $(\% 0,6)$ yer almaktadır (Tablo 7).

1 Ocak 2016 ve 1 Mayıs 2017 tarihleri arasında; kadınların sorunlarıly ilgili başlatılan toplam 226 adet kampanyanın 26'sı değişim yaratarak başarılı olmuştur. Belirlenen bu başarı oranı; hedeflenen imza sayısına ulaşmayı değil, istenilen değişimi ifade etmektedir. Muhataplarına göre en fazla başarılı olan kampanyalar; medya kuruluşları ve RTÜK'e gönderilen kampanyalar olarak saptanmıştır (\%35,8). Bu sıralamayı; özel kuruluş ve şirketler $(\% 21,7)$, siyasal partiler (\%19), TBMM $(\% 15,6)$, Cumhurbaşkanlığı (\%10), Bakanlık $(\% 9,7)$, güvenlik ve adli birimler $(\% 6,3)$ ve başbakanlık $(\% 3,2)$ izlemektedir. Tablo 8 'de de belirtildiği üzere diğer alıcılara gönderilen kampanyalarda herhangi bir değişim/başarı saptanmamıştır.

\section{TARTIŞMA VE SONUÇ}

Madun/kadınlar hem Gramsci'nin hem de Spivak'ın tanımlarında ötekiliği barındırmakta olup, bu ötekiliğin en büyük sorunsalı ise 'kadınların söylem alanı' olarak yer almaktadır. Kadınlar, sessizliğe bağlı olarak gittikçe büyük bir sarmalın içerisine girmektedir. Ataerkil toplum yapısı kadınları toplumsal cinsiyet ekseninde sıkıştırmaktadır. Ancak gelişen yeni iletişim teknolojileriyle beraber toplumda 'öteki' olarak yer alan ve öznenin dışında kalan bireylerin söylem alanlarını artırmakta ve direnişi daha kolay bir hale getirmektedir. Böylece daha önce ele aldığımız gibi yeni medya ile birlikte gelişen dijital aktivizm, hegemonya karşısında durabilmek için alternatif kanalların oluşmasına olanak sağlamaktadır.

Dijital aktivizmin küresel olarak önemli bir oluşum olan change.org'ta yer alan, kadınların sorunlarına yönelik başlatılan kampanyaların çoğunluğu değişim/başarı yaratmamış olsa dahi, maduna konuşma ve hatta kampanyalar aracılığıyla yeni bir örgütlenme alanı sunduğu için, madunun söylem alanının gelişmesi bağlamında önem arz etmektedir. Kadınlar dijital aktivist hareketle, maruz kaldığı şiddet, cinsiyet ayrımcılığı, eşitsiz istihdam koşulları ve bunun gibi bazı sosyal haklar kapsamında yeni bir alan yaratıp sesini duyurabilmekte ve destek olanlarla beraber kamuoyu yaratabilmektedir. Dolayısıyla Spivak'ın ortaya attığı "Madun konuşabilir mi?" sorunsalı üzerinde bir değerlendirme yapılacak olursa, madunun yeni medya ile birlikte konuşabilme potansiyelinin artırılabileceğini, böylece madun olmaktan çıkabileceğini göstermiştir. 
Araştırma kapsamında elde edilen bir diğer önemli bulgu ise kadınların sorunları kapsamında hangi konuların ağırlıklı olduğudur. İstihdam, eğitim, fırsat eşitliği gibi sosyal hakları ilgilendiren konular ve şiddet vakalarından sonra başlatılan kampanyaların varlığı, ülkemizdeki kadınların sorununun ne ölçüde önemli olduğunu da kanıtlar niteliktedir. Verilere göre; kadınlara şiddet vakaları niceliksel olarak fazla olmakla beraber, kadınların en büyük sorunlarından bir diğeri; medyada yer alan kadınların temsilidir.

Kampanyaları çoğunlukla kadınların başlatması, söz konusu internet sitesinin özellikle 'kadınlara' söylem alanı yarattığının kanıtıdır. Ancak erkekler de kadınların karşılaşı̆ı̆ı sorunlarla ilgili kampanyaları başlatmakta, yani madun adına konuşabilmektedir. Erkeklerin ağırlıklı olarak, madun adına söylem geliştirdiği konu; kadınlara yönelik şiddet konusudur.

Change.org'ta başlatılan kadınların sorunlarına yönelik olarak başlatılan kampanyalarda çoğunlukla siyasi erkler muhatap alınmış ve başlatılan kampanyalar hükümet başta olmak üzere her türlü siyasal mekanizmaya iletilmiştir. Bu durum, kadınları madun konumundan çıkararak özne konumuna getirmede siyasi erklerin üzerine birtakım görevler düştüğünü kanıtlar niteliktedir. Örneğin, kadınların hem sosyal hem de ekonomik statülerini iyileştirmek, şiddeti azaltmak için toplumun prototipini temsil eden TBMM'de sandalye kazanmış siyasi partilerin ve özellikle de hükümetin gerekli politikaları oluşturarak, uygulamaya geçirmeleri gerekliliği bir gerçektir.

Tüm bunların sonucunda diyebiliriz ki; yeni medya ve yeni teknolojiler toplumsal yapıyı dönüştürmek, madunu konuşturabilecek ve onu madun olmaktan kurtarabilecek alternatif kanallar açılmasına olanak tanımıştır. Geleneksel medyada seslerini duyuramayan, fiziksel olarak bir toplumsal hareketi başlama gücü olmayan ve suskun kalan madunlar dijital aktivizmin boyutlarının genişlemesiyle ezilenler ve ötekiler olarak birleşebilmekte, değişime katkı sağlayabilmektedir. İnsanların sanal olarak harekete geçmesini sağlayan change.org kampanyaları belli bir düzeyde amaçlarına ulaşan madunların sesi olmayı başarmış, onları madun olmaktan söylem bağlamında kurtarmıştır.

\section{KAYNAKLAR}

Andrejevic, M. (2014). Eleştirel medya çalışmaları 2:0 etkileşimli bir üst sürüm (L. Keskiner, Trans.). In M. Çakır (Ed.), Yeni medyaya eleştirel yaklaşımlar (pp. 55-81). İstanbul: Doğu Kitabevi. 
Aydın, F. (2017, November 23). Hasbro'nun seksist reklamı yayından kaldırılsın. Retrieved from https://goo.gl/ jdp86U

Castells, M. (2007). Communication, power and counter-power in the network society. International Journal of Communication 1, 238-266.

Change.org. (2017, May 7). Retrieved from https://www.change.org

Christensen, H. (2011). Political activities on the Internet: Slacktivism or political participation by other means?. First Monday, 16(2). doi:http://dx.doi.org/10.5210/fm.v16i2.3336

Considine, S. (2009). Homepage: Internet activism and women. Field:journal, 3 (1), 133-142.

Dahlberg, L. (2017). Dijital demokrasiyi yeniden yapılandırmak: Dört pozisyona dair bir taslak (M. A. Minarlı, Trans.). In Filiz Aydoğan (Ed.), Yeni medya kuramları (pp. 131-156). İstanbul: Der Yayınları.

Demirci, S., \& Köseli, M. (2011). İkincil veri ve içerik analizi. (Ed. K. Böke), Sosyal bilimlerde araştırma yöntemleri (pp. 321-362). İstanbul: Alfa Yayınları.

Doğu, B., Özçetin, B., Bayraktutan, G., Binark, M., Çomu, T., Aydemir, T. A., \& İslamoğlu, G. (2014), Siyasetin yeni hali vak-i sosyal medya. İstanbul: Kalkedon Yayınları.

Gramsci, A. (1971). Selections from the prison notebooks of Antonio Gramsci. New York: International Publishers.

Gramsci, A. (1971). History of the subaltern classes: Methodological criteria, selections from the prison notebooks of Antonio Gramsci. (Q. Hoare \& G. N. Smith, Trans.). New York: International Publishers.

Kahn, R., \& Kellner, D. (2004). New media and internet activism: From the 'Battle of Seattle' to blogging. New Media Society, 1 (6), 87-95.

Kıvılcım Z. (2009). İnsan hakları ve karşı hegemonya. Gazi Üniversitesi Hukuk Fakültesi Dergisi, 13(1-2), $217-240$.

Lewis, K. Gray, K., \& Meierhenrich, J. (2014). The structure of online activism. Sociological Science, 1, 1-9.

Öğülmüş, S. (1991). İçerik çözümlemesi. Ankara Üniversitesi Eğitim Bilimleri Fakültesi Dergisi,24(1), 213-228.

Slactivism. (2017, May 5). In Oxford. Retrieved from https://en.oxforddictionaries.com/definition/slacktivism

Somay, B. (2008). Çokbilmiş özne. İstanbul: Metis Yayınları.

Spivak, G. C. (2009). Madun konuşabilir mi? In D. Hattatoğlu \& G. Etuğrul (Ed.) (Hattatoğlu \& G. Etuğrul, Trans), Methodos: Kuram ve yöntem kenarından (pp. 53-114). İstanbul: Anahtar Kitaplar.

Uçkan, Ö. (2012)."Dijital aktivizm mi?"“'Aktivizm mi?”. Retrived from http://spotdergi.wordpress.com/2012/05/30/ dijital-aktivizm-mi-aktivizm-mi/

Yegen, C. (2014). Bir dijital aktivizm biçimi olarak Slaktivizm: Change.org örneği. Karadeniz Teknik Üniversitesi Iletişim Araştırmaları Dergisi, 8, 84-108. Retrieved from http://dergipark.gov.tr/ktuiad/issue/10315/126536

Yetişkin E. (2010). Tarde'ın toplum yaklaşımı açısından kamuoyu ve maduniyet. Iletişim Kuram ve Araştırma Dergisi, 2010(31), 1-28.

Yetişkin, E. (2013). Postkolonyal düşünce ve madun çalışmalarından neler öğrenebiliriz? Paper presented at the 13. Ulusal Sosyal Bilimler Kongresi, Ankara. 


\section{TABLOLAR VE EKLER}

Tablo 1: 01/01/2016 ve 01/05/2017 tarihleri arasında change.org'ta yer alan kadınların sorunlarına ilişkin kampanyaların oranları

\begin{tabular}{|c|c|c|}
\hline Toplam kampanya sayısı: & Başarılı olan kampanya sayısı: & Başarı Yüzdesi: \\
\hline 226 & 26 & $\% 11,5$ \\
\hline
\end{tabular}

Tablo 2: $01 / 01 / 2016$ ve 01/05/2017 tarihleri arasında change.org'ta yer alan kadınların sorunlarına ilişkin kampanya temaları ve başarı oranları

\begin{tabular}{|c|c|c|c|}
\hline Konu & Kampanya Sayısı & Başarılı Kampanya Sayısı & Başarı Yüzdesi \\
\hline ŞiDDET & 101 & 11 & $\% 10,8$ \\
\hline SOSYAL \& HUKUKi HAKLAR & 76 & 4 & $\% 12,5$ \\
\hline $\begin{array}{c}\text { MEDYADA KADINLARIN } \\
\text { TEMSiLi }\end{array}$ & 49 & 14 & $\% 28,5$ \\
\hline
\end{tabular}

Tablo 3: 01/01/2016 ve 01/05/2017 tarihleri arasında change.org'ta yer alan kadınların sorunlarına ilişkin kampanyaları başlatma oranları

\begin{tabular}{|c|c|c|}
\hline Kampanyayı Başlatan (Kaynak) & Sayı & Oran \\
\hline Kadın & 130 & $\% 57,5$ \\
\hline Erkek & 59 & $\% 26,1$ \\
\hline Kampanya Örgütlenmesi & 37 & $\% 16,3$ \\
\hline TOPLAM & $\mathbf{2 2 6}$ & $\mathbf{\% ~ 1 0 0}$ \\
\hline
\end{tabular}

Tablo 4: 01/01/2016 ve 01/05/2017 tarihleri arasında konularına göre kadınların başlattığı kampanyalar

\begin{tabular}{|c|c|c|}
\hline $\begin{array}{c}\text { Kadınların Başlattığı Kampanya } \\
\text { Temaları: }\end{array}$ & Kampanya Sayısı & Oran \\
\hline Şiddet & 52 & $\% 40$ \\
\hline Sosyal ve Hukuki Haklar & 42 & $\% 53,2$ \\
\hline Medyada Kadınların Temsili & 30 & $\% 23$ \\
\hline TOPLAM & $\mathbf{1 3 0}$ & $\mathbf{\% 1 0 0}$ \\
\hline
\end{tabular}


Tablo 5: 01/01/2016 ve 01/05/2017 tarihleri arasında konularına göre erkeklerin başlattığı kampanyalar

\begin{tabular}{|c|c|c|}
\hline $\begin{array}{c}\text { Erkeklerin Başlattığı Kampanya } \\
\text { Temaları: }\end{array}$ & Kampanya Sayısı & Oran \\
\hline Şiddet & 35 & $\% 59,3$ \\
\hline Sosyal ve Hukuki Haklar & 18 & $\% 30,3$ \\
\hline Medyada Kadınların Temsili & 6 & $\% 10,1$ \\
\hline TOPLAM & $\mathbf{5 9}$ & $\mathbf{\% ~ 1 0 0}$ \\
\hline
\end{tabular}

Tablo 6: $01 / 01 / 2016$ ve 01/05/2017 tarihleri arasında konularına göre örgütlenmelerin başlattığı kampanyalar

\begin{tabular}{|c|c|c|}
\hline $\begin{array}{c}\text { Örgütlerin Başlattığı Kampanya } \\
\text { Temaları: }\end{array}$ & Kampanya Sayısı & Oran \\
\hline Şiddet & 14 & $\% 37,8$ \\
\hline Medyada Kadınların Temsili & 13 & $\% 35,1$ \\
\hline Sosyal ve Hukuki Haklar & 10 & $\% 27$ \\
\hline TOPLAM & $\mathbf{3 7}$ & $\mathbf{\% 1 0 0}$ \\
\hline
\end{tabular}

Tablo 7: 01/01/2016 ve 01/05/2017 tarihleri arasında kadınların sorunlarına ilişkin kampanyaların alıcıları

\begin{tabular}{|c|c|c|}
\hline Kampanya Muhatapları (Alıcılar) & Alıcı Sayısı & Oran \\
\hline Bakanlık & 144 & $\% 29,3$ \\
\hline Medya Kuruluşları \& RTÜK & 53 & $\% 10,8$ \\
\hline STK \& Dernek & 47 & $\% 9,5$ \\
\hline Güvenlik \& Adli Birimler & 43 & $\% 8,7$ \\
\hline TBMM & 32 & $\% 6,5$ \\
\hline Başbakanlık & 31 & $\% 6,3$ \\
\hline Yerel Yönetim & 30 & $\% 6,1$ \\
\hline Özel Kuruluş - Şirket & 23 & $\% 4,6$ \\
\hline Siyasal Partiler & 21 & $\% 4,2$ \\
\hline Cumhurbaşkanlığı & 20 & $\% 4$ \\
\hline Şahıs & 17 & $\% 3,4$ \\
\hline Kamuoyu & 15 & $\% 3$ \\
\hline TDK & 12 & $\% 2,4$ \\
\hline Okul & 3 & $\% 0,6$ \\
\hline TOPLAM: & 491 & $\% 100$ \\
\hline
\end{tabular}


Tablo 8: 01/01/2016 ve 01/05/2017 tarihleri arasında kampanya alıcılarına göre başarı oranları

\begin{tabular}{|c|c|c|c|}
\hline $\begin{array}{l}\text { Kampanya Muhatapları } \\
\text { (Alıcılar) }\end{array}$ & Alıcı Sayısı & $\begin{array}{c}\text { Başarılı Kampanyalarda } \\
\text { Alıcı Sayısı }\end{array}$ & Başarı Yüzdesi \\
\hline Bakanlık & 144 & 14 & $\% 9,7$ \\
\hline Medya Kuruluşları \& RTÜK & 53 & 19 & $\% 35,8$ \\
\hline STK \& Dernek & 47 & - & - \\
\hline Güvenlik \& Adli Birimler & 43 & 3 & $\% 6,3$ \\
\hline TBMM & 32 & 5 & $\% 15,6$ \\
\hline Başbakanlık & 31 & 1 & $\% 3,2$ \\
\hline Yerel Yönetim & 30 & - & - \\
\hline Özel Kuruluş - Şirket & 23 & 5 & $\% 21,7$ \\
\hline Siyasal Partiler & 21 & 4 & $\% 19$ \\
\hline Cumhurbaşkanlığı & 20 & 2 & $\% 10$ \\
\hline Şahıs & 17 & - & - \\
\hline Kamuoyu & 15 & - & - \\
\hline TDK & 12 & - & - \\
\hline Okul & 3 & - & - \\
\hline
\end{tabular}

\section{EK 1: Kodlama Listesi}

D1: Kampanyaların Başarı Oranlarını Mesaja Göre Ölçümleme:
1. Şiddet
2. Sosyal ve Hukuki Haklar
3. Medyada Kadın Temsili

D2: Kampanyaların Başarı Oranlarını Kaynağa Göre Ölçümleme
1. Kadın
2. Erkek
3. Kampanya Örgütlenmesi

D3: Kampanyaların Başarı Oranlarını Alıcıya Göre Ölçümleme
1. Bakanlık
2. Medya Kuruluşları ve RTÜK 
3. Sivil Toplum Kuruluşu ve Dernek

4. Güvenlik ve Adli Birim

5. TBMM

6. Başbakanlık

7. Yerel Yönetim

8. Özel Kuruluş ve Şirket

9. Siyasal Partiler

10. Cumhurbaşkanlığı

11. Şahıs

12. Kamuoyu

13. TDK

14. Okul 
